Journal of Social Sciences 3 (1): 7-17, 2007

ISSN 1549-3652

(C) 2007 Science Publications

\title{
Responsibilities of Graduate Student: The Review of Research Student Policies
}

\author{
${ }^{1}$ Norhasni Zainal Abiddin, ${ }^{2}$ Mel West \\ ${ }^{1}$ Department of Professional Development and Continuing Education, Faculty of Educational Studies \\ Universiti Putra Malaysia, 43400 Serdang, Selangor, Malaysia \\ ${ }^{2}$ School of Education, Humanities Building, The University of Manchester, Oxford Road, Manchester \\ M13 9PL, United Kingdom
}

\begin{abstract}
The researcher's previous study had found that most research students did not fully used their graduate research student policy as point of reference. Objective was to review the contents of the research student policy and the benefits of having systematic policies for the supervision of research students. Total of 40 graduate research student policies had been studied from 40 well established universities in the United Kingdom. We focused on the responsibilities of research student which stated in the policies. The results from this research had found that all the universities reviewed had their own research student policies. However, not all of them had clearly spell-out their respective policies in the student handbook. In the mean time, some universities had established additional aspects or information and they were systematically as well as precisely presented. Hence, the additional information or detailed guidelines presented by these particular universities were considered very useful in establishing the research student policy for the benefits of the student, supervisor as well as the school.
\end{abstract}

Keywords: PhD, graduate student, handbook, policy, supervision, responsibility

\section{INTRODUCTION}

The research student policies are designed as a guideline to enable students to complete their degrees successfully within the time limits. The research student policies typically also defines the responsibilities of students and supervisors, suggesting what each can reasonably expect of the other and gives examples of good supervisory practice. Basically, the research student policies can be used as a guideline by the supervisor, student and department. The policies are intended to provide a framework for research in an atmosphere of scholarship and collegiality.

Research student policies can be found under many different names, such as code of practice for research students, quality assurance in research degrees, research degrees regulations, code of conduct, ethical principles and guidelines, postgraduate procedures or memoranda to graduate students. Generally, research student policies are one of the main topics highlighted in the Student Handbook. These topics were: about the department, patterns of the programme, supervision and regulations relating to theses. They are referred to as a code of practice for the purpose of this research. Some of the universities have elaborated these four topics in detail, whereas others say relatively little about them. In practice, different universities have different ways of presenting their Student Handbooks. Generally the purpose of the Student Handbook is to introduce student to the school as well as university-wide procedures, facilities and services for research degree students. It is compiled from a range of sources and serves a variety of purposes. Figure 1 has been developed to clarify the contents of the handbooks, summarising the relevant aspects. However this research will concentrate on the supervision section or research student policies and only focusing on the responsibilities of the student.

Generally, the students are given the Student Handbook on their admission day so they should be aware of it and understand its contents clearly. In this way, they can get to know many things related to their life as a PhD student and how to manage their research throughout their programme. The guidelines in the handbook about the responsibilities of the student, the responsibilities of the supervisor, the responsibilities of the department and supervisory patterns and practices that appear in research student policies can be very supportive to the students during their study. This research identifies the existence of the graduate research student policies from all the universities reviewed and other related information in relation to

Corresponding Author: Norhasni Zainal Abiddin, Department of Professional Development and Continuing Education, Faculty of Educational Studies, Universiti Putra Malaysia, 43400 Serdang, Selangor, Malaysia, 


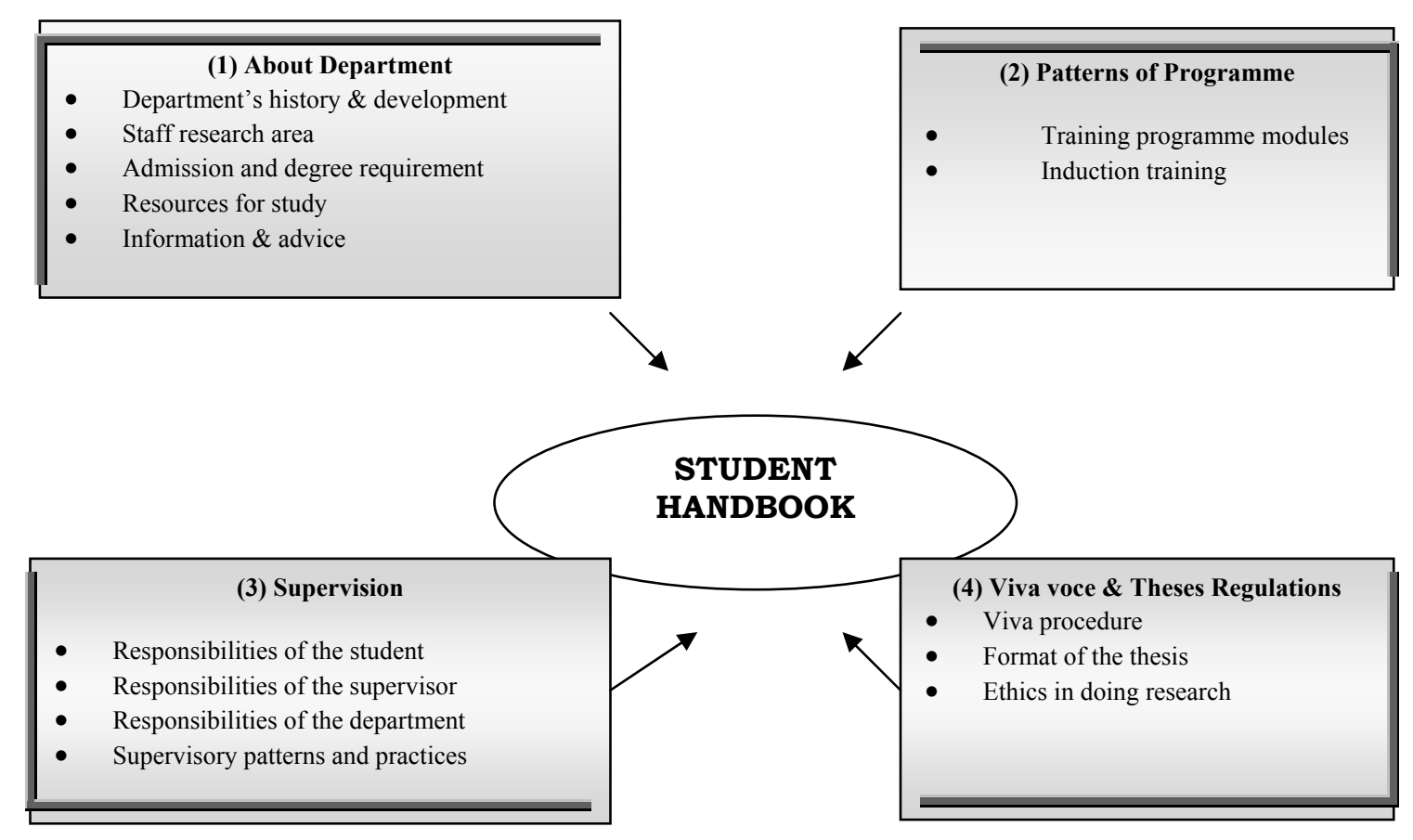

Note: (1) to (4) = Code of practice, (3) = Research student policies

Fig. 1: The main topics listed in student handbooks

supervision. By studying the policies, people will be having clear information which universities had the information that other universities do not. The combination of those related information will strengthen the research student policies and would benefit the student, supervisor and school. Furthermore, there were no previous studies were done which similar to this research. When the policies were clearly and systematically stated, the related person will definitely be able to overcome any inquiries or problems in relation to supervision. For instance, it was very common that the students having problem with their supervisor but do they really know what to do? If the policies were systematic and clear, each and every involved party will be able to use this policy as point of reference and can be used at any situations. Therefore, this research clearly unwrap the content of research student policies which focusing on students responsibilities.

\section{MATERIALS AND METHODS}

Policies on research students have been reviewed from forty universities in the United Kingdom. The researcher has managed to access the policies of each university by searching the website (the full website addresses are presented in the bibliography). These forty universities were selected because they are all top ranking universities in the United Kingdom. The majority of the research student policies were located by using the search column and typing in the words 'handbook' or 'code of practice'. Unfortunately some of the top ranking universities do not display their Student Handbooks on their website, so that there had to be obtained by post.

A literature search has provided evidence that the student/supervisor relationship is vital to the $\mathrm{PhD}$ process. The literature includes statements about the single most important problem, in the eyes of many respondents, being the quality of supervision ${ }^{[1]}$. Various books have approached the acquisition of $\mathrm{PhDs}$, including the management of the supervisor/student relationship ${ }^{[2]}$ and many departments carry out their own surveys in an attempt to assess their performance in the supervision of their students ${ }^{[3]}$.

Phillips and $\mathrm{Pugh}^{[2]}$ point out that the acquisition of skills by postgraduate students should be effected as professional learning conducted under their own management. In other words, research students have to take responsibility for managing their own learning and 
getting a PhD. They are also responsible for determining what is required as well as for carrying it out and must always keep in touch in regular meetings with the supervisor ${ }^{[4-6]}$. Moses ${ }^{[7]}$ argues that supervisors expect students to be diligent, hardworking, energetic, keen, tenacious and conscientious and to have a sense of urgency. They also expect students to be enthusiastic and motivated towards research work, to be pleasant at work and to contribute to a good working environment. Also, students should give continual feedback, so that the supervisor can give informed instruction.

The student is the main person responsible for his/her PhD research. Doing a PhD clearly indicates that this is a student's own research and work. Phillips and $\mathrm{Pugh}^{[2]}$ emphasise that it is the student's responsibility to determine what is required as well as carrying it out and that students have to come through with the clear aim of becoming a competent professional researcher. In other word, it is agreed that the student is responsible for an original contribution to the subject and for developing a mature, critical knowledge of the subject area and its context. It is also a good idea for them to talk to other postgraduates about their experience of the role as well as their work. Russell $^{[8]}$ found that one of the highly rated constraints on research students' are personal problems. In fact, sharing apprehensions helps to resolve problems through the knowledge that the problem is not an individual one ${ }^{[9]}$. Once students are able to share feelings and talk about them and their effect on their work, they will all start to feel better $^{[8]}$.

Students should identify the topic and preliminary reading ${ }^{[10]}$. This can be linked with other parts of the $\mathrm{PhD}$ task, like the development of a relevant body of knowledge, placing the research in the context of the literature and originality ${ }^{[3,8,11]}$. Moses ${ }^{[4]}$ and Phillips and Pugh $^{[2]}$ elaborate this statement mentioning that the process of defining the research topic varies across disciplines. The supervisor in a science discipline has to take the lead in obtaining the physical resources and the research personnel required. The student's research topic will be clearly defined to fit in with the innovative thrust of the supervisor's research programme. In contrast, in the humanities and social sciences, students often come with their own topics within the field in which the supervisor is expert. Additionally, after surveying aspects of graduate education in Canadian universities, Holdaway et al. ${ }^{[12]}$ report that in education, social sciences and humanities, graduate students choose their thesis topics themselves more frequently than those in other disciplines do.
The thesis is usually the most substantial piece of writing yet undertaken by students and it provides an opportunity for them to develop their skills in writing and in marshalling arguments ${ }^{[3]}$. On the other hand, they should submit written work in some form as early as possible in their studies so that writing problems can be recognised and corrected ${ }^{[13]}$. Donald et al. ${ }^{[14]}$ propose that the responsibilities of the student should include understanding the scope of doctoral work, such as the number of years to be devoted to full time study, knowledge of research methods necessary to carry out studies, the regulations on thesis submission and the expectations of the supervisor regarding every aspect of the research.

A good student should have a broader view of academic training in the discipline in which he/she is undertaking the research, seeing it as professional development ${ }^{[2]}$. In this sense, professional development include attending conferences, writing papers for publication, attending seminars and workshops, making presentations, networking with other researchers, working as a research assistant and teaching ${ }^{[2,10,12,15]}$. Students are expected to gain expertise in the research process so that their talents can be observed in as many different settings as possible ${ }^{[10]}$.

Most overseas students are sponsored by appropriate bodies during their study. They have been given a specific period, namely three years, to complete their study and return to their own country. Therefore, time is one of the enemies of the overseas student. This is relevant to the study conducted by Russell ${ }^{[8]}$, who found that students are concerned about time and time management. Lack of funding seriously affects some students' research, or requires them to partly self-fund it and this results in serious concerns and deep frustration $^{[12,16]}$. This view is supported by the Economic and Social research Council (ESRC) which reported that less than $20 \%$ of students receiving a grant complete their study within four years while $27 \%$ complete within five years and that completion rates trailed off markedly after five years ${ }^{[17]}$. So, students should expect to work within deadlines ${ }^{[2,11,18,19]}$ and to have a planned timetable ${ }^{[20-23]}$.

\section{RESULTS AND DISCUSSION}

This section discusses the responsibilities of the research students from year one until the end of their research programme. It also touches on the responsibility of students towards their sponsors. Three of the universities reviewed point out in the handbook the important events in the life of the research student. 
This makes it easier for the student to check where they should be at the different stages and what they are supposed to do next. However, though the guidelines are mentioned, they depend on the agreement made by both parties about supervisory arrangements and on the student's willingness to follow them through. As shown in Table 1, one of the universities reviewed provided a checklist on good supervisory practices and a summary and recommendations regarding the code of practice on the management of higher degrees undertaken by overseas students. This includes the important events from year one until third year and students are recommended to work harder if the answer to the selfassessment questions on the list is 'no' or 'not yet'. Such information was very important in order to strengthen the research student policy while other universities had not highlighted them.

A new student should attend the Induction Training Programme provided by the school shortly after student registration. This is because a student can get to know many new and important things by attending. Generally, as good students, they must be familiar with the requirements of their department and these are likely to be covered during induction. At the very beginning of the programme, students must define the area of their research in consultation with their supervisor. It is easier for students if they are continuing previous research, like their Master's research, because they will already have a clear idea about the literature. At this stage, postgraduate students must make an effort to evaluate their own strengths and weaknesses.

The student must also be aware of subject related issues, such as safety requirements if they working in a laboratory dealing with dangerous materials. In some of the universities reviewed, which offered students lots of science courses, safety in the laboratory has become an important aspect that has been highlighted in their policies. Of course, it is not only the student and supervisor who have responsibilities in the laboratory, for research workers and technicians may also be involved. Students must inform their supervisors of any new procedure they wish to carry out within the laboratory. As mentioned in several of the handbooks reviewed, before embarking on a project, it is the responsibility of the student to consider the nature of the technical support that might be involved in running an experiment and to establish through discussion with the supervisor how that will be organised. Appropriate notice must be given to the technical support staff before the starting date of any projects. Students may not carry out any new procedure or use any potentially hazardous equipment without first obtaining permission from the supervisor or other relevant staff, ensuring that an adequate risk assessment has been carried out and completing adequate training.

In order to enable new students to develop knowledge and experience in doing research, most departments will provide them with research training programme. It is the student's responsibility to attend appropriate training courses required by the department or recommended by the supervisor. Such training programmes usually consist of a series of modules designed to cover a range of competencies, involving data collection and analysis methods, the use of information technology and presentational skills. It is also designed to raise awareness of more general issues relating to theory, ethics and practice. To underline its importance, some universities give their students a Postgraduate Certificate in Research Methods when they have completed the course successfully.

During their studies, students are expected to gain key skills. The idea is that the supervisor and student will work together on developing these over the period of the research. Among the important skills that the student should gain while doing a $\mathrm{PhD}$ are writing skills, including drafting, planning; receiving and acting on feedback; writing papers for submission to conferences if appropriate, undertaking state of the art surveys and writing these up with an appropriate critical stance; and planning research, including time plans and plan monitoring. The required skills also include the effective use of time and working to deadlines; use of a research diary; giving verbal presentations and answering questions; use of visual aids; methods of scientific and engineering research practice, like good laboratory practice; assembling and using the right IT (Information Technology) tools; self management, organising and managing their work; and understanding professional behaviour and the ethics of research.

One of the universities reviewed mentioned that international students can experience a number of special problems, relating to things like tuition fees and English proficiency and general problems in understanding the British academic system and the type of work required for a British higher degree. Therefore, it is a good idea for them to meet very regularly with their supervisors, for example, once a week for the first few months, to help them become acclimatised to the UK academic culture. Students are required to demonstrate reasonable proficiency in English before they are accepted for a postgraduate programme and it is their responsibility to acquire the standard of English required for academic work during their stay. 
Table 1: Synthesizing research student policies in forty selected universities

\begin{tabular}{|c|c|c|c|c|c|c|c|}
\hline University & $\begin{array}{l}\text { Student's } \\
\text { Responsibilities }\end{array}$ & $\begin{array}{l}\text { Supervisor's *1 } \\
\text { Responsibilities }\end{array}$ & $\begin{array}{l}\text { Department's *2 } \\
\text { Responsibilities }\end{array}$ & $\begin{array}{l}\text { Supervision } \\
\text { Practices }\end{array}$ & $\begin{array}{l}\text { Induction } \\
\text { Training }\end{array}$ & $\begin{array}{l}\text { Code of } \\
\text { Practice* }\end{array}$ & Others \\
\hline 1. Aberdeen ${ }^{[24]}$ & $\checkmark$ & $\checkmark$ & $\checkmark$ & $\checkmark$ & $\mathrm{x}$ & $\checkmark$ & \\
\hline 2. Bath $^{[25]}$ & $\checkmark$ & $\checkmark$ & $\checkmark$ & $\checkmark$ & $\checkmark$ & $\checkmark$ & $\begin{array}{l}\text { Important events from } \\
\text { years } 1-3\end{array}$ \\
\hline 3. Birmingham $^{[26]}$ & $\checkmark$ & $\checkmark$ & $\checkmark$ & $\checkmark$ & $\checkmark$ & $\checkmark$ & Responsibility of mentor \\
\hline 4. Bristol $^{[27]}$ & $\checkmark$ & Adviser & $\checkmark$ & $\checkmark$ & $\mathrm{x}$ & $\checkmark$ & \\
\hline 5. Brunel ${ }^{[28]}$ & $\checkmark$ & $\checkmark$ & $\begin{array}{l}\text { Head of } \\
\text { Department }\end{array}$ & $\checkmark$ & $\mathrm{x}$ & $\checkmark$ & \\
\hline 6. Cambridge ${ }^{[29]}$ & $\checkmark$ & $\checkmark$ & $\checkmark$ & $\checkmark$ & $\mathrm{x}$ & $\checkmark$ & \\
\hline 7. City ${ }^{[30]}$ & $\checkmark$ & $\checkmark$ & Research Director & $\checkmark$ & $\checkmark$ & $\checkmark$ & $\begin{array}{l}\text { Internally/externally } \\
\text { registered student }\end{array}$ \\
\hline $\begin{array}{l}\text { 8. College } \\
\text { London }^{[31]}\end{array}$ & $\checkmark$ & $\checkmark$ & $\checkmark$ & $\checkmark$ & $\mathrm{x}$ & $\checkmark$ & $\begin{array}{l}\text { Women advisers \& } \\
\text { graduate tutor }\end{array}$ \\
\hline 9. De Monfort ${ }^{[32]}$ & $\checkmark$ & $\checkmark$ & $\checkmark$ & $\checkmark$ & $\checkmark$ & $\checkmark$ & \\
\hline 10. Dundee ${ }^{[33]}$ & $\checkmark$ & $\checkmark$ & $\checkmark$ & $\checkmark$ & $\checkmark$ & $\checkmark$ & $\begin{array}{l}\text { Good supervisory practice } \\
\text { checklist, management of } \\
\text { overseas students }\end{array}$ \\
\hline 11. Durham ${ }^{[34]}$ & $\checkmark$ & $\checkmark$ & $\begin{array}{l}\text { Postgraduate } \\
\text { Director }\end{array}$ & $\checkmark$ & $\checkmark$ & $\checkmark$ & $\begin{array}{l}\mathrm{PhD} \text { year plan from } 1^{\text {st }} \text { to } \\
3^{\text {rd }} \text { year }\end{array}$ \\
\hline 12. Edinburgh ${ }^{\lfloor 35]}$ & $\checkmark$ & $\checkmark$ & $\checkmark$ & $\checkmark$ & $\mathrm{x}$ & $\checkmark$ & $\begin{array}{l}\text { Assistant and co } \\
\text { supervisor's role }\end{array}$ \\
\hline 13. $\operatorname{Exeter}^{[36]}$ & $\checkmark$ & $\checkmark$ & $\checkmark$ & $\checkmark$ & $\checkmark$ & $\checkmark$ & Peer support \& mentor \\
\hline 14. Glamorgon ${ }^{[37]}$ & $\checkmark$ & $\begin{array}{l}\text { Director of } \\
\text { Study }\end{array}$ & $\checkmark$ & $\checkmark$ & $\checkmark$ & $\checkmark$ & \\
\hline 15. Glasgow ${ }^{[38]}$ & $\checkmark$ & $\checkmark$ & $\begin{array}{l}\text { Head of } \\
\text { Department }\end{array}$ & $\checkmark$ & $\checkmark$ & $\checkmark$ & \\
\hline 16. Greenwich ${ }^{[39]}$ & $\checkmark$ & $\checkmark$ & School Director & $\checkmark$ & $\mathrm{x}$ & $\checkmark$ & \\
\hline $\begin{array}{l}\text { 17. Heriott- } \\
\text { Watt }\end{array}$ & $\checkmark$ & $\checkmark$ & $\checkmark$ & $\checkmark$ & $\mathrm{x}$ & $\checkmark$ & Mentor's role \\
\hline 18. Keele ${ }^{[41]}$ & $\checkmark$ & $\checkmark$ & $\checkmark$ & $\checkmark$ & $\mathrm{x}$ & $\checkmark$ & \\
\hline 19. Kent $^{[42]}$ & $\checkmark$ & $\checkmark$ & $\checkmark$ & $\checkmark$ & $\mathrm{x}$ & $\checkmark$ & Technical support \\
\hline 20. Lancaster ${ }^{[43]}$ & $\checkmark$ & $\checkmark$ & $\checkmark$ & $\checkmark$ & $\mathrm{x}$ & $\checkmark$ & $\begin{array}{l}\text { Special problems that } \\
\text { international students could } \\
\text { experience }\end{array}$ \\
\hline 21. Leeds ${ }^{[4]]}$ & $\checkmark$ & $\checkmark$ & $\checkmark$ & $\checkmark$ & $\mathrm{x}$ & $\checkmark$ & \\
\hline 22. Leicester ${ }^{[45]}$ & $\checkmark$ & $\checkmark$ & $\checkmark$ & $\checkmark$ & $\checkmark$ & $\checkmark$ & \\
\hline 23. Liverpool ${ }^{[46]}$ & $\checkmark$ & $\checkmark$ & $\checkmark$ & $\checkmark$ & $\checkmark$ & $\checkmark$ & \\
\hline
\end{tabular}

Hence many universities run language courses for international students to improve their English language. If students think that they need to improve their language, they must attend appropriate courses, after discussing them with their supervisor. International students may also find that they need extended periods of absence from the university for family reasons or data collection. They should inform their supervisors or the appropriate staff in the department of any periods when they intend to be abroad and should try to keep non-research related absences to a minimum. If an emergency occurs and the student cannot return to the country, he/she should inform his/her supervisor immediately. In exceptional circumstances, it may be necessary for the student to apply for a period of intercalation. Such guideline is very useful to the students and they will at least know what to do in this situation.
At the end of each academic year, basically the student must provide a brief formal report on progress to the department through the supervisor. This report can be used as evidence that a student is well on the way to completing his/her thesis. Normally, the first year progress report is especially important to the MPhil student wishing to transfer to the $\mathrm{PhD}$ programme. This report generally includes a summary of the key literature, the aims and objectives of the research project and a brief report of the results so far, the work for the next year and the plan of the work up till thesis submission.

Students must maintain a good relationship with their supervisor in order to enjoy their life as a $\mathrm{PhD}$ student. Starting students must get in touch with their supervisor early, preferably before the official start of term and ensure that they fully understand the formal requirements of their degree. They should aim to get into a position to start well-focused work as soon as 


\begin{tabular}{|c|c|c|c|c|c|c|c|}
\hline University & $\begin{array}{l}\text { Student's } \\
\text { Responsibilities }\end{array}$ & $\begin{array}{l}\text { Supervisor's *1 } \\
\text { Responsibilities }\end{array}$ & $\begin{array}{l}\text { Department's *2 } \\
\text { Responsibilities }\end{array}$ & $\begin{array}{l}\text { Supervision } \\
\text { Practices }\end{array}$ & $\begin{array}{l}\text { Induction } \\
\text { Training }\end{array}$ & $\begin{array}{l}\text { Code of } \\
\text { Practice* }\end{array}$ & Others \\
\hline $\begin{array}{l}\text { 24. London } \\
\text { Goldsmiths }{ }^{[47]}\end{array}$ & $\checkmark$ & $\checkmark$ & $\begin{array}{l}\text { Departmental } \\
\text { Postgraduate } \\
\text { Group }\end{array}$ & $\checkmark$ & $\checkmark$ & $\checkmark$ & \\
\hline $\begin{array}{l}25 . \\
\text { Loughborough }^{[48]}\end{array}$ & $\checkmark$ & $\checkmark$ & $\begin{array}{l}\text { Director of } \\
\text { Research }\end{array}$ & $\checkmark$ & $\mathrm{x}$ & $\checkmark$ & \\
\hline 26. Manchester ${ }^{[49]}$ & $\checkmark$ & $\checkmark$ & $\checkmark$ & $\checkmark$ & $\checkmark$ & $\checkmark$ & \\
\hline 27. Middlesex ${ }^{[50]}$ & $\checkmark$ & $\checkmark$ & $\mathrm{x}$ & $\mathrm{x}$ & $\mathrm{x}$ & $\checkmark$ & \\
\hline 28. Nottingham ${ }^{[51]}$ & $\checkmark$ & $\checkmark$ & Head of School & $\checkmark$ & $\checkmark$ & $\checkmark$ & Women's adviser \\
\hline 29. Oxford $^{[52]}$ & $\checkmark$ & $\checkmark$ & $\mathrm{x}$ & $\mathrm{x}$ & $\checkmark$ & $\checkmark$ & \\
\hline 30. Reading ${ }^{[53]}$ & $\checkmark$ & $\checkmark$ & $\checkmark$ & $\checkmark$ & $\checkmark$ & $\checkmark$ & \\
\hline 31. Salford ${ }^{[54]}$ & $\checkmark$ & $\checkmark$ & $\mathrm{x}$ & $\checkmark$ & $\mathrm{x}$ & $\checkmark$ & \\
\hline 32. Sheffield ${ }^{[55]}$ & $\checkmark$ & $\checkmark$ & $\checkmark$ & $\checkmark$ & $\mathrm{x}$ & $\checkmark$ & \\
\hline $\begin{array}{l}33 . \\
\text { Southampton }{ }^{[56]}\end{array}$ & $\checkmark$ & $\checkmark$ & $\checkmark$ & $\checkmark$ & $\mathrm{x}$ & $\checkmark$ & \\
\hline 34. St. Andrews ${ }^{[57]}$ & $\checkmark$ & $\checkmark$ & $\checkmark$ & $\checkmark$ & $\checkmark$ & $\checkmark$ & \\
\hline 35 . Surrey ${ }^{[58]}$ & $\checkmark$ & $\checkmark$ & Head of School & $\checkmark$ & $\checkmark$ & $\checkmark$ & $\begin{array}{l}\text { Collaborative } \\
\text { supervisor }\end{array}$ \\
\hline 36. Sussex ${ }^{[59]}$ & $\checkmark$ & $\checkmark$ & $\checkmark$ & $\checkmark$ & $\checkmark$ & $\checkmark$ & $\begin{array}{l}\text { Collaborative \& } \\
\text { independent distance } \\
\text { student }\end{array}$ \\
\hline 37. $\mathrm{UMIST}^{[60]}$ & $\checkmark$ & $\checkmark$ & $\checkmark$ & $\mathrm{x}$ & $\checkmark$ & $\checkmark$ & Technician role \\
\hline $\begin{array}{l}\text { 38. Wales } \\
\text { Cardiff }\end{array}$ & $\checkmark$ & $\checkmark$ & $\begin{array}{l}\text { Head of } \\
\text { Department }\end{array}$ & $\checkmark$ & $\checkmark$ & $\checkmark$ & \\
\hline 39. Warwick ${ }^{[62]}$ & $\checkmark$ & $\checkmark$ & $\checkmark$ & $\checkmark$ & $\checkmark$ & $\checkmark$ & $\begin{array}{l}\text { Guidelines on stage } \\
\text { of } \mathrm{PhD} \text { research } \\
\text { from year } 1-3\end{array}$ \\
\hline 463] Westminster & $\checkmark$ & $\checkmark$ & Director of Study & $\checkmark$ & $\checkmark$ & $\checkmark$ & \\
\hline
\end{tabular}

possible. Agreement should be reached between both parties pertaining to the meeting arrangements and frequency. For example, one of the universities reviewed has recommended that meetings should be once a week during the first term and may then move on to being fortnightly when the work is well under way. The relationship with the supervisor might go wrong, so a student must know when to take initiative in raising problems or difficulties, however elementary they may seem. If a student believes that an effective working relationship has not been established, this should be brought to the attention of the Departmental Postgraduate Group, which will investigate the problem and if necessary, arrange for a new supervisor to be nominated.

Students have to discuss with their supervisor the type of guidance and comment they find most helpful, agreeing a schedule of meetings, initiating supervisory sessions where necessary and setting the agenda for supervisory sessions. It is important that they can express their own interests and ideas to their supervisor as early as possible and that they turn up to meetings well prepared, as they will be doing most of the talking. If, for some reason, students have nothing new to say, or they are in the middle of working something out, it may be preferable to postpone the meeting. It is also the responsibility of students to submit written work as and when required by their supervisor. Research work and progress may be discussed with the supervisor in many other ways as appropriate, like in meetings, by e-mail and on the telephone. Students are advised to rewrite sections before they go to the supervisor. The more students write and discuss the content and style of writing with their supervisor in the early years, the more straightforward will be the production of the first draft. If the supervisor does not request written work, then it is still the responsibility of the student to submit it because some supervisors give students freedom to plan their own research work as long as they can maintain progress in accordance with the plan agreed with them. In particular, written material should be submitted as required to the supervisor in sufficient time to allow for comments and discussion before proceeding to the next stage.

Time is the factor that often appears to be the student's worst enemy. It is important to be aware that the start of a project is nearly always much slower than expected and that although contextual knowledge is 
important, spending too long on background material, the literature survey, or complex data analysis using computing techniques can eventually result in noncompletion. As mentioned by one of the universities reviewed, the most important task is to set a timetable of work per week, showing the number of hours, which the student intends to devote to research study. Full time students are expected to work for at least thirtyfive hours a week. For instance, some departments give students a Research Planner and Record or Log Book. They can keep a written note of meetings with their supervisor, which should include items for action. Wherever possible it is the supervisor and student should agree to use the planner as a record in each meeting. Students can also use different ways to record the meetings with their supervisor as long as both parties are agreed. Clearly, the more students are able to do at an earlier stage according to the schedule agreed by both parties, the less pressured they will be at the end and the later they will be able to collect data and write the thesis. Based on advice in the various handbooks, writing should begin earlier than the third year and data collection should extend well into that year. It is, then, advisable for students to prepare a timetable agreed by supervisor in conducting their research. The timetable can be made on either a longterm or short-term basis, as applicable and should be useful as a guide for what to do next and when the work should be done and submitted. As mentioned by one of the universities reviewed, an important consideration when planning the timetable is to include holidays and other major commitments of student and supervisor. There is no point producing a draft when the supervisor is about to go on holiday or leave work for quite a long time.

After the student has passed the critical first year, there is time to be a little comfortable in the second year, because, in fact, he/she should have conducted a literature review and have a clear picture of the research to be undertaken by now. Social science or arts students will be working on data collection in the second year. Some students want leave to work away from university or do their fieldwork, but they are required to have a formal research plan and have to discuss it with their supervisor before they leave.

Throughout the period of $\mathrm{PhD}$ study, students are encouraged to talk to as many people as possible about their work. In other words, if they can explain clearly and intelligibly what they are doing to a friend who knows nothing about it, they will be able to explain it clearly in the thesis. Students are also advised to talk to experts in the field, if possible. This kind of interaction with other postgraduate students inside and outside the department can be motivating, supportive and widen students' perspectives and interests. For example, one of the universities reviewed mentioned that students are encouraged to maintain contact with their peers throughout the course of the programme and not to restrict communication to the regular workshops and seminars. This includes communication by e-mail because this is more flexible and efficient than face-toface contact, which is not always practicable.

Most departments in British universities will arrange a seminar to be attended by their staff and postgraduate students. Students are invited to participate in the seminar by giving ideas and they can also get much knowledge by attending the seminar or presenting their work in it. However some universities reviewed expected their students to conduct seminars in order to demonstrate readiness to upgrade to $\mathrm{PhD}$. Since students are still at an early stage in research, they are expected to discuss methods rather than substantive findings or conclusions in such seminars. Some students are encouraged by their supervisor to publish papers or articles. Although the first priority is to ensure that students complete their $\mathrm{PhD}$ on time, as they progress through doctoral study, they may want to consider publishing some of their work, but should first ask their supervisor for advice on this. Publishing is a means of disseminating research to a wider audience, but is also particularly important in order to be a successful academic. A few articles in good journals, enhances the CV (Curriculum Vitae) and increases the chances of getting that first academic job. However, students should consult with their supervisor on the appropriate recognition of their contribution to research publications in accordance with the university's policy on intellectual property rights. Students must also find their own expenses or grants if they want to present papers in conferences, regardless of whether the conference is far away from their current university.

The third year is for writing up the thesis. In writing a thesis, ethical issues can be seen as an important aspect. Students should accept the general principle that a thesis must be their own work and should not be based on confidential material, which would make it inaccessible. It is the responsibility of a research student to decide when to give notice of intention to submit and when to submit the thesis. This can be done after the minimum period of registration and within the time limits specified in regulations, taking due account of the supervisor's opinions. Most students will prepare their thesis themselves, but it is their responsibility to ensure that time still left for 
thorough proof-reading, catching up, checking references and so forth. Students should also be aware of their duty to present the final draft of their thesis to their supervisor and to seek advice on preparation for the oral examination. A few universities included in the review have emphasised that students must submit an abstract to the Director of Studies six months before they intend to submit. In addition, generally students must notify the University Registrar or Graduate Office at least two months before submission.

Some departments or schools may ask their postgraduate students to submit yearly supervision questionnaires to the Postgraduate Registry. This may be of benefit to research students, since it makes supervisors aware of their weaknesses in the supervision of their students. It enables the student to comment in confidence on the course structure, teaching delivery and workload. Some departments may also have a regular meeting with research staff and research students, once or twice a year. This is the forum for a student to make suggestions, raise concerns and give feedback on any aspects of study. Basically, the meetings help students to share their research experiences and to find solutions to their problems in doing the research. Crucially, students are also encouraged to obtain approval for their research from ethics committees where appropriate. They are furthermore encouraged to maintain communication with the department via electronic mail or e-mail, mailboxes or student pigeonholes.

Finally students are responsible to their sponsors. Most student who pursue their study abroad, are sponsored by their governments or certain funding bodies. Therefore, after completing their study, they normally have a contract to fulfil. They should inform their sponsors of the progress they have made on their project on a regular basis. Normally, students who are unable to complete within the prescribed period of time and have been granted an extension are on that account not automatically entitled to seek further advice. They may have to negotiate with their supervisor and in certain cases, the university may charge an additional fee. On the other hand, overseas students are encouraged by their sponsors to choose research topics that may benefit their country, as well as reflecting their interest.

As indicated in Table 1, one of the universities reviewed mentioned externally and internally registered students. Internally registered students are the ordinary ones that are assigned a supervisor in the same university. An externally registered student has an internal and an external supervisor. A periodic exchange of views between the supervisors and the student about the student's work is advised, through an agreed medium and at an agreed frequency. The university concerned recommends that the internal supervisor visits the student at least once during the academic year.

Whilst the supervisor's role is important, it should also be acknowledged that fellow students are an invaluable source of support and advice. Besides, one of the universities reviewed has highlighted the case of an independent distance student who was not in attendance at the university. Students are required to attend for a minimum of one term at the university depending on the requirements of the research programme. For the purpose of the maximum and minimum periods of registration permitted, an independent distance student was regarded as equivalent to a full time student. This is quite different from the situation of the collaborative distance student who not is in attendance at the university, but is carrying on research in the industry or institution with whom the university has established a collaborative agreement. In this latter case, attendance at the university is not required, unless it is specified by the Director of Study.

\section{CONCLUSION}

Literature had mentioned the importance of good relationship between the student and supervisor to ensure that the student could be able to complete their study timely. It is true that research students will greatly benefit from the advice and direction of good supervisors, but they themselves are ultimately responsible for their own research and the preparation of their theses. To successfully achieve the objective of completing a $\mathrm{PhD}$ programme, there are roles that the supervisor and the student must play. The student can gain much experience from doing the research, so long as it is his/her own, while the supervisor is there to give assistance where needed. Therefore, the responsibility of the student for his/her own work is very important in ensuring that he/she completes his/her study successfully.

Student should work hard towards completion of the $\mathrm{PhD}$ by taking into account the department and university regulations. As a mature student, one should work independently although the supervisor is there to provide guidance, advice, support and encouragement where appropriate. Those who think the policies are very useful and helpful may see the handbook as a place of reference if something goes wrong or the 
student needs more explanation in relation to supervision or studies.

Notwithstanding, as students, they were exposed with the supervision related information, but how clear were they towards the information? Sometimes, the information had been ignored at that time since it was not related and only needed in the future. So, where the reference could be obtained? This is where the importance of the graduate research student policy. The related information on study programme in general and supervision specifically can be obtained from there. The guidelines were clearly stated and can be applied by the student, supervisor and the school when they need it. Therefore, this research had found that all the 40 universities reviewed had presented their graduate research student policies systematically. However, there were few other universities had presented their policies more precisely and clearly where some other universities had not done it. Hence, such information is applicable for the policy makers in order to improvise their policies. Such information could be used as place of reference especially for the students and all involved parties to gain the benefit from there.

\section{REFERENCES}

1. Buckley, P.J. and J. Hooley, 1988. The noncompletion of doctoral research in management: Symptoms, causes and cures. In Haksever, A.M. and E. Manisali, 2000. Assessing supervision requirements of $\mathrm{PhD}$ students: The case of construction management and Engineering in the UK. European J. Engineering Education, 25: 1932.

2. Phillips, E.M. and Pugh, D.S., 2000. How to get a PhD- A handbook for students and their supervisors. Buckingham: Open University Press.

3. Haksever, A.M. and E. Manisali, 2000. Assessing supervision requirements of $\mathrm{PhD}$ students: The case of construction management and Engineering in the UK. European J. engineering education, 25: 19-32.

4. Moses, I., 1992. Good supervisory practice. In Holdaway, E., Deblois, C. and I. Winchester, 1995. Supervision of graduate students. The Canadian J. Higher Education, XXV: 1-29.

5. Powles, M., 1989. How's your thesis going? In Holdaway, E., Deblois, C. and I. Winchester, 1995. Supervision of graduate students. The Canadian J. Higher Education, XXV: 1-29.

6. Powles, M., 1993. Staff development for $\mathrm{PhD}$ supervision. In Philips, E.M. and Pugh, D.S., 2000. How to get a PhD. Milton Keynes: Open University Press.
7. Moses, I., 1985. Supervising Postgraduates. In Holdaway, E., Deblois, C. and I. Winchester, 1995. Supervision of graduate students. The Canadian J. Higher Education, XXV: 1-29.

8. Russell, A., 1996. Postgraduate research: Student and supervisor Views. The Flinders University of South Australia.

9 Arksey, H., Marchant, I. and Simmill, C., 1994. Juggling for a degree- Mature students' experience of university life. Lancaster: Unit for Innovation in Higher Education.

10. Brown, R.D. and L. Krager, 1985. Ethical issues in graduate education: Faculty and student responsibilities. J. Higher Education, 56: 403-418.

11. Salmon, P., 1992. Achieving a PhD- Ten students' experience. Staffordshire: Trentham Books Limited.

12. Holdaway, E., Deblois, C. and I. Winchester, 1995. Supervision of graduate students. The Canadian J. Higher Education, XXV: 1-29.

13. Spear, R.H., 2000. Supervision of research students: Responding to student expectations. The Australian National University, Canberra.

14. Donald, J.G., Saroyan, A. and B. Denison, 1995. Graduate student supervision policies and procedures: A case study of issues and factors affecting graduate study. The Canadian J. Higher Education, XXV: 71-92.

15. Alfonso, R.J. and R. Firth, 1990. A research agenda: Supervision needed research. J. Curriculum and Supervision, 5: 181-188.

16. Hofman, A. and D. Berg, 2000. Determinants of study progress: The impact of student, curricular and contextual factors on study progress in university education. Higher Education in Europe, XXV: 93-110.

17. Elton, L. and M. Pope, 1987. Social science PhD completion rates. Research Intelligence, BERA Newsletter, February. In Haksever, A.M. and E. Manisali, 2000. Assessing supervision requirements of $\mathrm{PhD}$ students: The case of construction management and engineering in the UK. European J. Engineering Education, 25: 1932.

18. Science and Engineering Research Council (SERC), 1983. Research student and supervisor: An approach to good supervisory practice. London: SERC.

19. Yeatman, A., 1995. Making supervision relationships accountable: Graduate student logs. Australian Universities' Review, 38: 9-11.

20. Bowen, W.G. and Rudenstine, N.L., 1992. In pursuit of the $\mathrm{PhD}$. Princeton, NJ: Princeton University Press. 
21. Frischer, J. and K. Larsson, 2000. Laissez-faire in research education - An inquiry into a Swedish Doctoral Program. Higher Education Policy, 13: 132-155.

22. Cryer, P., 2000. The research student's guide to success. Buckingham: Open University Press.

23. Rudd E., 1985. A new look at postgraduate failure. In Acker, S., Hill, T. and E. Black, 1994. Thesis supervision in the social science: Managed or negotiated? Higher Education, 28: 483-498.

24. University of Aberdeen, 2004. PhD Handbook. http:// www. abdn.ac.uk/management/phd8.hti

25. University of Bath, 2004. Postgraduate Research Student Handbook 2002-2003. http://www. bath.ac.uk/ psychology/ pg/pghandbook 2002and3.cfm

26. University of Birmingham, 2004. Code of Practice on Admission, Monitoring and Assessment of Research Students. http:/ /www.a o.bham.ac. uk/aps/ regs/co295-3.htm

27. University of Bristol, 2004. Graduate Handbook 1999-2000. http:/ /www.bris. ac.uk/Depts /ArtsPGC/ agchb99.htm

28. University of Brunel, 2004. Course Handbook. http:/ /www.brunel. ac.uk/faculty/ tech/faculty/ engd/handbook/ super.htm

29. University of Cambridge, 2004. PhD HandbookStudying for a $\mathrm{PhD}$ Degree. http:/ /www.sps. cam.ac.uk /gradstudies /phdhand book.html

30. City University, 2004. Research Studies- Role and Responsibilities. http:/ /www.city. ac.uk/ researchstudies/roles.htm

31. University College London, 2004. Handbook for Graduate Students 2002-2003. http:/ /www.phon. ucl.ac.uk/ dept/student_information/pghb2002.pdf

32. University of De Monfort, 2004. Responsibilities of Supervisors and of Students. http: //www.dmu.ac. uk/research/regs_and_procedures/ Res_Deg_Regs. jsp?ComponentID $=3937 \&$ Source PageID $=1358 \# 1$

33. University of Dundee, 2004. Code of Practice for Supervised Postgraduate Research. http:/ /www.dundee. ac.uk/learning /qau/qualin dex/newcode. htm

34. University of Durham, 2004. Postgraduate Supervision Procedures. http:/ /www.dur. ac.uk $/ \sim \mathrm{dcs} 0 \mathrm{www} /$ postgrad /Pgrad Procedures. html

35. University of Edinburgh, 2004. Supervisors. http:/ /www. postgrad. ed. ac.uk /RESCODE/ Supervisors. htm
36. University of Exeter, 2004. Responsibilities of Supervising. http: //www. ex. ac.uk/ pgms /research/

37. University of Glamorgan, 2004. Policies and Handbooks. http: // www .glam.ac.uk/ research/policies/

38. University of Glasgow, 2004. Guidance Notes for Research Students. http: //www. medicine. gla.ac. $\mathrm{uk} / \mathrm{rstu} /$ Guidelines. htm

39. University of Greenwich, 2004. Code of Practice for Postgraduate Research. http:/ /www. gre.ac.uk/ students/office /RRP/ codes/ research.htm

40. Heriot-Watt University, 2004. Quality Assurance Procedures and Good Practice. http: //www. hw.ac.uk /quality/ QRM2001/ contents.html

41. University of Keele, 2004. Code of Practice on Postgraduate Research Degrees. http: //www. keele.ac. uk/depts/ aa/postgraduate /cop/

42. University of Kent, 2004. Orientation Handbook for Postgraduate Students in the Department of Psychology 2002-03. http:// www.ukc. ac.uk/ psychology/ handbooks/pg/ index. htm\#code

43. University of Lancaster, 2004. PhD By ResearchStudent Handbook 2002-2003. http: //www. psych. lancs.ac. uk/pg/ PhDRes HB.html

44. University of Leeds, 2004. Code of Practice for Postgraduate Research Study. http:// www. psyc.leeds. ac.uk/docs/PGCodeof Prac. pdf

45. University of Leicester, 2004. A Handbook for Research Student. http:// www.le.ac. uk/education/ research/ research_student/ research student handbook/ contents.html

46. University of Liverpool, 2004. Code of Practice for Postgraduate Research Students and Supervisors. http:// www. qaa.ac.uk/ public/ COP/cop/ contents. $\mathrm{htm}$

47. Goldsmith College, University of London, 2004. Information for Staff-Research and Postgraduate Research Students. http: // www. gold. ac.uk / staffinfo /hb6-5. html

48. University of Loughborough, 2004. Research Student Handbook 2002-2003. http: //www.lboro. ac.uk/departments/ ss/postgrads/ pg_student_handbook.htm

49. University of Manchester, 2004. Graduate Handbook. http: //www. gssem. man.ac.uk/ graduate/ graduate handbook. htm

50. University of Middlesex, 2004. Research Degree Regulations. http: // www.mdx. ac.uk/ research /docs/ rdreg .pdf 
51. University of Nottingham, 2004. Postgraduate Handbook 2003. http:/ /www.maths .nottingham. ac.uk/ postgraduate/ pghand book/ yoursupervisor. htm

52. University of Oxford, 2004. Guidelines for Graduate. http: // www. ling-phil. ox. ac. uk/ postgrad /general. html

53. University of Reading, 2004. University Code of Practice on Research Students. http: //www. rdg. ac.uk/ Handbooks/ Teaching_and_Learning /Code of Practice. html

54. University of Salford, 2004. Code of Practice for the Conduct of Postgraduate Research Degree Programmes. http: // www. academic. salford. ac.uk/ aqa/ apps/ Appendix21.pdf

55. University of Sheffield, 2004. Responsibilities of the Supervisor. http: //www. shef.ac.uk/ gradsch /Info ForStudents/ Responsibilities/ Supervisor. html

56. University of Southampton, 2004. Handbook for Research Students. http: //www. socstats. soton.ac.uk/teach/ research- handbook. pdf

57. University of St. Andrews, 2004. A Code of Practice for Supervisors and Students in Taught and Research Postgraduate Programmes. http: // www. standrews. ac.uk /services /registry /pgcodind. htm
58. University of Surrey, 2004. Code of Practice for Research Degrees. http: // www.o pen. mis.surrey. ac.uk/ admin/ registry/ qaeo/ ASG/ coprd. pdf

59. University of Sussex, 2004. Research Handbook. http: //www. sussex. ac.uk /Units/ academic/ academicoffice /committees /graduate /handbooks/ GRCDirectors-hdk.pdf

60. UMIST, 2004. General Policy. http: // www2. umist. ac. Uk /Materials/ depment/ Safety/ 2.0\% 20 General \%20 Policy. htm

61. University of Wales, Cardiff, 2004. Quality Assurance in Research Degrees: Code of Practice. http: // www. cf. ac. uk/ areg/ quality /aq sm/ part 4/

62. University of Warwick, 2004. Code of PracticeQuality and Standard in Higher Education. http: // www. qaa. ac. uk/ public / COP/ cop/ guid 7_12. htm\#super

63. University of Westminster, 2004. Research Students Guide. http :// www. wmin. ac. uk/ csd/ Research \% 20 Student \%2 0Guide \% 2099 -00. $\mathrm{htm}$ 